\title{
Copper tolerance of three Crotalaria species from southeastern D.R. Congo at the early development stage
}

\author{
Sylvain Boisson, Soizig Le Stradic, Morgane Commans, Amandine Dumont, \\ Natasha Leclerc, Cynthia Thomas, Grégory Mahy \\ University of Liège - Gembloux Agro-Bio Tech. BIOSE. Biodiversity and Landscape Unit. Passage des Déportés, 2. BE- \\ 5030 Gembloux (Belgium).E-mail: sylvain.boisson@ulg.ac.be
}

Received on April 23, 2015; accepted on November 12, 2015.

Description of the subject. Microevolutionary processes in metallophytes established on copper enriched soils can lead to a diversity of plant species showing distinct tolerance capacities among genus. Researches about the relationship between these endangered plants and soil copper concentrations are critical in order to improve ex situ conservation methods in southeastern Democratic Republic of Congo (Katangan Copperbelt).

Objectives. The aim of the study was to test the effect of copper on the germination and root elongation of three Crotalaria species naturally occurring along a natural copper gradient. The hypothesis is that copper concentrations have different effects on germination and root elongation according to the species of Crotalaria genus.

Method. Three species were selected: Crotalaria cobalticola, Crotalaria peschiana and Crotalaria cornetii, occurring on soils with the highest to the lowest copper concentrations respectively. Germination and root elongation tests were performed in vitro (MS vitamin-enriched medium) in six copper mediums ranging from 0 to $125 \mu \mathrm{M} \mathrm{Cu}^{2+}$.

Results. No significant differences in germination percentage were observed according to the copper concentrations. Crotalaria cornetii had the lowest germination percentage. Root elongation of $C$. peschiana did not differ with copper concentration, but root elongation of $C$. cobalticola was higher at the greatest copper concentration $\left(125 \mu \mathrm{M} \mathrm{Cu}^{2+}\right)$.

Conclusions. Even if $C$. cobalticola presented better growth at highest $\mathrm{Cu}$ concentrations, it appeared that $C$. cobalticola and C. peschiana do not require copper for their early stages of development and could thus be conserved in non-contaminated substrate. Crotalaria cornetii seemed to present a physical seed dormancy.

Keywords. Crotalaria, biodiversity conservation, indigenous organisms, seed germination, root length, in vitro experimentation, copper, soil chemicophysical properties, D.R. Congo.

Tolérance au cuivre de trois espèces de Crotalaria de l'Arc Cuprifère Katangais dans les premiers stades de croissance Description du sujet. Les processus microévolutifs des métallophytes établies sur des sols naturellement enrichis en cuivre peuvent conduire à une diversité d'espèces végétales présentant des capacités de tolérance distinctes au sein d'un genre. Dans l'Arc Cuprifère katangais (sud-est de la R.D. Congo), l'étude des relations entre les espèces menacées et leurs conditions édaphiques est essentielle pour améliorer les méthodes de conservation ex situ.

Objectifs. L'objectif de l'étude est de tester l'effet de la concentration en cuivre sur la germination et la croissance racinaire de trois espèces de Crotalaria, présentes le long d'un gradient de cuivre. L'hypothèse est que les concentrations en cuivre ont un impact différent sur la germination et l'élongation des racines selon l'espèce du genre Crotalaria.

Méthode. Trois espèces du genre Crotalaria ont été sélectionnées : Crotalaria cobalticola, Crotalaria peschiana et Crotalaria cornetii, présentes sur des sols avec des concentrations en cuivre respectivement des plus élevées aux plus faibles. Des tests de germination et d'élongation racinaire ont été effectués pour six concentrations en cuivre échelonnées de 0 à $125 \mu \mathrm{M} \mathrm{Cu}{ }^{2+}$. Résultats. Les résultats n'ont mis en évidence aucun effet des concentrations en cuivre sur le pourcentage de germination. Crotalaria cornetii a présenté les plus faibles pourcentages de germination. L'élongation racinaire de C.peschiana n'a pas différé en fonction des concentrations en cuivre, cependant l'élongation racinaire de $C$. cobalticola était plus grande à la concentration en cuivre la plus élevée $\left(125 \mu \mathrm{M} \mathrm{Cu}^{2+}\right)$.

Conclusions. Même si $C$. cobalticola présente une meilleure croissance à des concentrations en cuivre plus élevées, il apparait que $C$. cobalticola et $C$. peschiana ne nécessitent pas de cuivre dans leurs premiers stades de développement et peuvent donc être conservées dans un milieu non enrichi en cuivre. Une probable dormance physique des graines pourrait affecter la germination de C. cornetii. 
Mots-clés. Crotalaria, conservation de la diversité biologique, organisme indigène, germination des graines, longueur des racines, expérimentation in vitro, cuivre, propriété physique du sol, R.D. Congo.

\section{INTRODUCTION}

Metalliferous areas present high concentrations of trace metals associated with other environmental constraints including xericity and poor depauperate nutrient content (Ernst, 1974; Kruckeberg, 1985). These harsh abiotic conditions are strong drivers for local adaptation of plant species (Antonovics et al., 1971; Brady et al., 2005) that results in the formation of highly distinctive plant communities (Duvigneaud et al., 1963; Ernst, 1974; Rajakaruna, 2004; Saad et al., 2012). Such ecosystems are found in many places around the world (e.g. Arizona, Peru, Chili, Australia or Democratic Republic of Congo). They are usually recognized as major hotspots of biodiversity (Whiting et al., 2004; Veldman et al., 2015), offering outstanding examples of microevolution and speciation processes (Antonovics et al., 1971; Faucon et al., 2010; Harrison et al., 2011).

Ecosystems established on soils naturally enriched with copper are rare, except in South Central Africa where occurs a large number of copper-cobalt mineralized areas (Duvigneaud et al., 1963; Baker et al., 2010; Chipeng et al., 2010). The Katangan Copperbelt, in the Katanga province (South East of Democratic Republic of Congo), extends over 300 km long between Kolwezi and Lubumbashi with more than 150 copper- and cobalt-rich outcrops (François, 1988; Cailteux et al., 2005). These outcrops appear as isolated hills scattered in the Miombo woodland matrix, and available copper concentrations often exceed $10,000 \mathrm{mg} \mathrm{Cu} \cdot \mathrm{kg}^{-1}$ at the outcrop summit. Those copper hills support more than 550 metallophyte taxa (Leteinturier, 2002). Recent studies show that trace metals and related nutrient concentrations play a significant role to structure plant communities along the metal gradient (Saad et al., 2012; Ilunga wa Ilunga et al., 2013; Séleck et al., 2013).

In Katanga, copper hills represent a biodiversity hotspot (Malaisse, 1983; Brooks et al., 1985; Leteinturier et al., 2002; Faucon et al., 2010), including 56 endemic species in which 32 are exclusively restricted to copper enriched soils (absolute metallophytes) (Faucon et al., 2010). Some authors have shown that the edaphic endemism could result of both abiotic and biotic interactions (Meyer, 1986; Palacio et al., 2007). First, taxa may be restricted to a limited area because of their specialization to particular physicochemical soil conditions making them more competitive than in regular soils (Meyer, 1986). Second, taxa can be stress-tolerant, but not specifically adapted, to adverse physicochemical conditions, and take refuge in the stressful area where competition with other plant species is lowest (Gankin et al., 1964). Plants of the Katanga (D.R. Congo) occurring on copper-rich soils remained poorly studied (Faucon et al., 2012). To focus on endemic and non-endemic species within a genus appears interesting in order to understand the relationship between plant and copper concentrations in soil.

The copper hills have been severely disturbed for more than one century through the mining of natural resources leading in some cases to their degradation or total destructions (Brooks et al., 1992; Faucon et al., 2010). The determination of the in vitro multiplication ability of some endemics appears useful in a purpose of ex situ conservation. In this paper, we aimed to test the effect of copper on the germination and the root elongation of Crotalaria cobalticola, Crotalaria peschiana and Crotalaria cornetii. The results also contribute to discuss the relationship between the endemic status of the three species and their affinity for copper.

\section{MATERIALS AND METHODS}

We investigated both the germination and the root elongation in the first weeks according to different copper concentrations for three species of the genus Crotalaria (Fabaceae) from the Katangan Copperbelt. These species, Crotalaria cobalticola, Crotalaria peschiana and Crotalaria cornetii, were chosen according to their supposed copper tolerances (i.e. present in their habitat) and their endemism status in natural ecosystem; C. cobalticola, being the most tolerant species to strong copper concentrations and C. cornetii the less tolerant species.

\subsection{Plant species}

Crotalaria is a genus of the Fabaceae family. The genus Crotalaria appears to be mainly adapted to the seed dispersal by wind, water and gravity (Le Roux et al., 2011). Crotalaria cobalticola P.A. Duvign. \& Plancke is a strict endemic and a threatened species (proposed IUCN status: EN) present in the natural highest $\mathrm{Cu}$-enriched steppes of the copper hills or in disturbed copper and cobalt soils in the Katangan Copperbelt (Figure 1, Table 1). This annual forb has a natural density of about 5 to 10 individuals $\cdot \mathrm{m}^{-2}$ and was identified as an hyper-accumulator of cobalt in concentrations higher than $3,000 \mathrm{mg} \cdot \mathrm{kg}^{-1}$ (Duvigneaud et al., 1959; Brooks et al., 1981). Crotalaria cornetii 

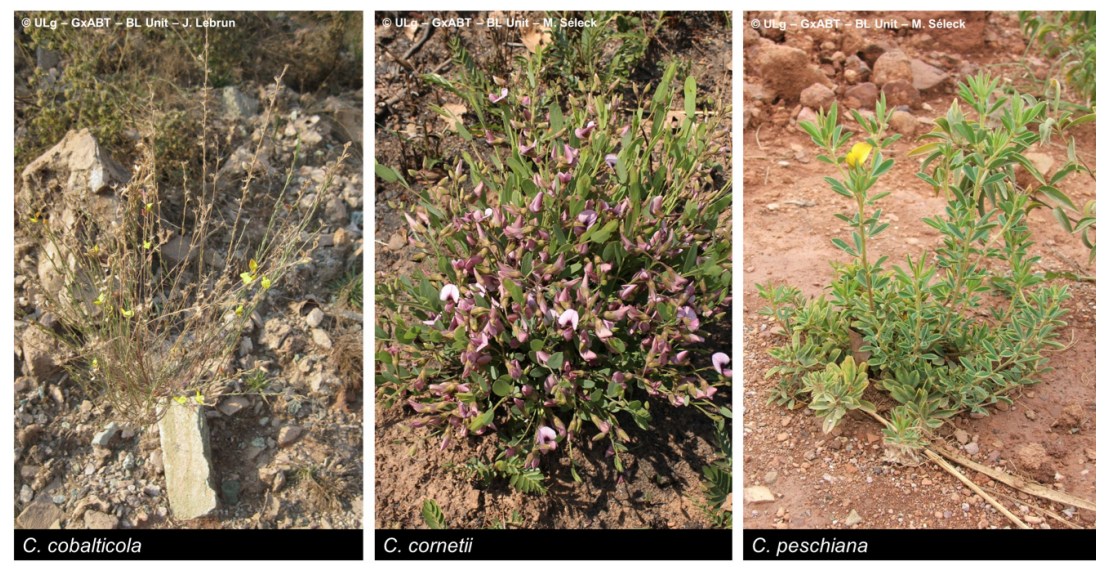

Figure 1. Pictures of adult individuals of the three tested Crotalaria species Photographies des individus adultes des trois espèces testées de Crotalaria (http://copperflora.org/eflora).

Taub. \& Dewevre is a non-endemic species presenting a large distribution in the southeastern D.R. Congo with a density of about 0.5 to 1 individual per $\mathrm{m}^{2}$. It occurs on the low-enriched substrate (Figure 1, Duvigneaud et al., 1963), located in the steppic savannahs of the copper hills (Table 1, Duvigneaud et al., 1959). To date, its IUCN status has not been assessed. Crotalaria peschiana P.A. Duvign. \& Timp. is a strict endemic and a critically endangered species (proposed IUCN status: CR) occurring in the slopes of steppic savannah of the natural copper hills in the Katangan Copperbelt (Duvigneaud et al., 1959; Faucon et al., 2010). Its natural density is about 1 to 2 individuals per $\mathrm{m}^{2}$ (Figure 1, Table 1).

\subsection{Seed collection}

Seeds were harvested in populations occurring in the southeastern D.R. Congo, in the Copperbelt, between the cities of Tenke $\left(10.61^{\circ} \mathrm{S} ; 26.12^{\circ} \mathrm{E}\right)$ and Fungurume $\left(10.62^{\circ} \mathrm{S} ; 26.32^{\circ} \mathrm{E}\right)$ during the year 2013. This region presents 40 isolated copper hills between $1,300 \mathrm{~m}$ to $1,400 \mathrm{~m}$. The climate is subtropical with a rainy season from November to the end of March and a dry season from May to September. October and April are the transition months between the two seasons. Annual rainfalls are ca. $1,300 \mathrm{~mm}$, most of which occur during the rainy season. Temperatures range from $15^{\circ} \mathrm{C}$ to $17^{\circ} \mathrm{C}$ at the beginning of the dry season and from $31{ }^{\circ} \mathrm{C}$ to $33^{\circ} \mathrm{C}$ between September and October. Dry season minima can reach $5{ }^{\circ} \mathrm{C}$ at night (Saad et al., 2012).

Seeds were collected on 72 individuals scattered in one population of $C$. cobalticola (ca. 100-500 individuals), on 75 individuals in one population of $C$. cornetii (ca. 100-500 individuals) and on 75 individuals in one population of $C$. peschiana (ca. 500-1,000 individuals). Among population, mature and well-developed individuals were targeted in order to obtain mature seeds. For the three species, fruits are dehiscent pods and seed sizes comprised between 3 and $5 \mathrm{~mm}$. Crotalaria cornetii has largest seeds $(4-5 \mathrm{~mm})$ (Table 1). For each species, seeds from the different individuals were pooled and seed samples were then placed in conserva-

Table 1. General characteristics of the studied species - Caractéristiques générales des espèces étudiées.

\begin{tabular}{llllllll}
\hline Taxon & Life form & $\begin{array}{l}\text { Habitat in } \\
\text { copper hills }\end{array}$ & Fruiting time & Fruit type & Seed size & $\begin{array}{l}\text { Proposed } \\
\text { IUCN status }\end{array}$ & $\begin{array}{l}\text { Conservation } \\
\text { status }\end{array}$ \\
\hline $\begin{array}{l}\text { Crotalaria } \\
\text { cobalticola }\end{array}$ & Annual & $\begin{array}{l}\text { Highly Cu/Co- } \\
\text { enriched steppe }\end{array}$ & April-May & Dehiscent pod & $3-4 \mathrm{~mm}$ & EN & Strict endemic \\
$\begin{array}{l}\text { Crotalaria } \\
\text { cornetii }\end{array}$ & Perennial & $\begin{array}{l}\text { Low Cu/Co- } \\
\text { enriched steppic } \\
\text { savannah }\end{array}$ & $\begin{array}{l}\text { September- } \\
\text { October }\end{array}$ & Dehiscent pod & $4-5 \mathrm{~mm}$ & NA & Non-endemic \\
$\begin{array}{l}\text { Crotalaria } \\
\text { peschiana }\end{array}$ & Perennial & $\begin{array}{l}\text { Cu/Co-enriched } \\
\text { slope }\end{array}$ & $\begin{array}{l}\text { August- } \\
\text { September } \\
\text { (April-May) }\end{array}$ & Dehiscent pod $3-4 \mathrm{~mm}$ & CR & Strict endemic \\
\hline
\end{tabular}

Habitat descriptions and life forms are from Duvigneaud et al. (1959), Duvigneaud et al. (1963) and Saad et al. (2012). Conservation status and proposed IUCN status are from Faucon et al. (2010). Fruiting time, fruit type, seed sizes are from field observations $-\mathrm{La}$ description des habitats et les formes de vies proviennent des travaux de Duvigneaud et al. (1959), Duvigneaud et al. (1963) et Saad et al. (2012). Les statuts de conservation et les statuts UICN proviennent de Faucon et al. (2010). Les périodes de fructification, les types de fruits et les dimensions des graines proviennent d'observations de terrain ; CR: Critically endangered - fort en danger; EN: Endangered - en danger; NA: Not assessed - non évalué. 
tion. Considering that the three species have different conservation purposes (i.e. short-term conservation for $C$. cornetii and C.peschiana and long-term conservation for C. cobalticola), they were stored in different sites during a maximum two years. Crotalaria cobalticola was stored in the Botanic Garden Meise (Belgium) at $-20{ }^{\circ} \mathrm{C}$ and $15 \% \mathrm{RH}$ in order to apply long term conservation strategy (Godefroid et al., 2013). The two other species (C.cornetii and $C$. peschiana) were conserved at $5{ }^{\circ} \mathrm{C}$ in the nursery of Tenke Fungurume Mining Sarl (D.R. Congo) in order to use their seeds in propagation programs (Table 2 ).

\subsection{Germination tests}

Germination tests were performed in controlled conditions between October and December 2014. Mediums were prepared with agar $\left(8 \mathrm{~g} \cdot \mathrm{l}^{-1}\right)$, Murashige and Skoog (MS)-vitamins $\left(2.2 \mathrm{~g} \cdot \mathrm{l}^{-1}\right)$, sucrose $\left(10 \mathrm{~g} \cdot \mathrm{l}^{-1}\right)$, MES-buffer $\left(0.5 \mathrm{~g} \cdot \mathrm{l}^{-1}\right)$ and copper sulfate solution $\left(\mathrm{CuSO}_{4} .5 \mathrm{H}_{2} \mathrm{O} 0.1 \mathrm{M}\right)$. Six copper mediums were prepared: 0 (the control), 25, 50, 75, 100 and $125 \mu \mathrm{M}$ (i.e. $\mu \mathrm{mol} \cdot \mathrm{l}^{-1}$ ) copper added, based on the results of Chipeng et al. (2010) and two other studies about nontolerant legumes (Di Salvatore et al., 2008; Lin, 2011). The $\mathrm{pH}$ was adjusted at 5.7 with $\mathrm{HCl} 0.5 \mathrm{M}$ or $\mathrm{NaOH}$ $0.1 \mathrm{M}$. Fifty $\mathrm{ml}$ of medium were put in each Petri dish; each medium was previously sterilized in autoclave during $90 \mathrm{~min}$.

In order to limit the pathogen development, seeds were first treated with a bleach water solution $(5 \%)$ during $5 \mathrm{~min}$ and rinsed three times with distilled water followed by a 5 min soak in an ethanol solution (70\%) (Boisson et al., 2016). Seeds were then rinsed again three times in distilled water. Then, for each species and for each copper concentration, 90 seeds were placed in three Petri dishes (i.e. 30 seeds by Petri dish according to a systematic grid following six columns and five rows).

Petri dishes were placed horizontally in a tropical growth chamber with photoperiod $12 / 12$ at $25^{\circ} \mathrm{C}$ and $70 \%$ relative humidity at $450 \mu \mathrm{E}$ light and $15^{\circ} \mathrm{C}$ and $50 \%$ relative humidity in the dark during 38 days
(23 October - 01 December). Germination was recorded when the radicle was at least $2 \mathrm{~mm}$ long. Germination was monitored twice a week during three weeks and once a week as soon as one germinated seed maximum was recorded by Petri dish.

\subsection{Root elongation tests}

In vitro elongation tests were performed for C. cobalticola and C.peschiana; the number of $C$. cornetii seedlings was too low in order to test the effect of copper on root elongation. The root elongation test mediums were the same than the germination mediums; 0 (the control), 25, 50, 75, 100 and $125 \mu \mathrm{M}$ (i.e. $\mu \mathrm{mol} \cdot \cdot^{-1}$ ) copper added. Seedlings were germinated on MS, and transplanted when cotyledons appeared after a treatment with bleach water (10\%) during 5 min followed by five rinsing baths in distilled water in order to keep it in sterile conditions. For each species and for each copper concentration, ten seedlings were transplanted in two Petri dishes (i.e. five seedlings by Petri dish) and dishes were installed vertically in the same conditions than for the germination tests during four weeks. The distance $(\mathrm{mm})$ between the crown and the apical point of the roots was measured at the end of the test.

A first test demonstrated the independence of seedlings root elongation among the Petri dishes. For this purpose, seedlings were germinated in the non-enriched MS. Five seedlings were transplanted respectively in five Petri dishes while five seedlings were transplanted in one Petri dish. The final distance $(\mathrm{mm})$ between the crown and the apical point of the roots was also measured.

\subsection{Data analysis}

Germination percentages were calculated as the ratio between the number of germinated seeds and total number of seeds in a Petri dish. Cumulative germination curves were created in order to evaluate the global dynamic of the germination process. The

Table 2. Location of harvested sites with collecting and conservation data of the seeds of the three studied species - Localisation des sites de récoltes des espèces et des informations sur la collecte et la conservation des graines des trois espèces.

\begin{tabular}{|c|c|c|c|c|c|c|}
\hline \multirow[t]{2}{*}{ Taxon } & \multicolumn{3}{|c|}{ Collecting date } & \multicolumn{3}{|c|}{ Conservation data } \\
\hline & Date & Site & Sampled ind. & Date & Method & Site \\
\hline Crotalaria cobalticola & $07 / 05 / 2013$ & Fungurume II & 72 & $28 / 05 / 2013$ & $-18{ }^{\circ} \mathrm{C}-15 \%$ HR & BGM \\
\hline Crotalaria cornetii & 03/01/2013 & Kavifwafwaulu I & 75 & $02 / 01 / 2013$ & $5{ }^{\circ} \mathrm{C}$ - ambient HR & TFM \\
\hline Crotalaria peschiana & $24 / 09 / 2013$ & Kazinyanga & 75 & $24 / 09 / 2013$ & $5^{\circ} \mathrm{C}-$ ambient $\mathrm{HR}$ & TFM \\
\hline
\end{tabular}

BGM: Botanic Garden Meise; TFM: Tenke Fungurume Mining sarl. 
mean germination time (MGT) was calculated as a proxy of the germination speed:

$$
\sum_{t_{0}}^{t_{f}} \frac{g_{t i}-p_{t i}}{N_{g}}
$$

where $t_{0}$ was the beginning of the test (in days); $t_{f}$ was the time at test closure (in days); $g_{t i}$ was the number of germinated seeds at the time $t_{i} ; p_{t i}$ was the period (in days) between $t_{i}$ and $t_{0} ; N_{g}$ was the total number of germinated seeds (Ellis et al., 1981). The effect of copper concentration on both the final germination percentages and on the mean germination time (MGT) was analyzed by a one-way ANOVA.

Effect of copper concentration on root elongation was assessed using one-way ANOVA. The independence test had confirmed the absence of effect of the Petri dishes on the root elongation (one-way ANOVA C. cobalticola: $F=1.03, p$-value $>0.05$; one-way ANOVA $C$. peschiana: $F=3.59, p$-value $>$ $0.05)$. So, ten replications were considered for the analysis. However, some seedlings died during the test. The number of replications was lower than 10 in two treatments for C. cobalticola $(25 \mu \mathrm{M}, \mathrm{n}=9 ; 75 \mu \mathrm{M}$,

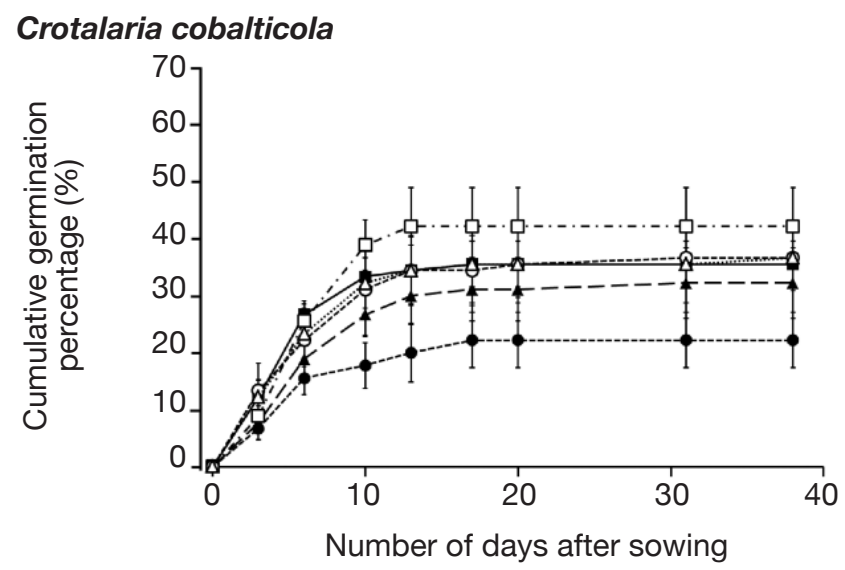

\section{Crotalaria peschiana}

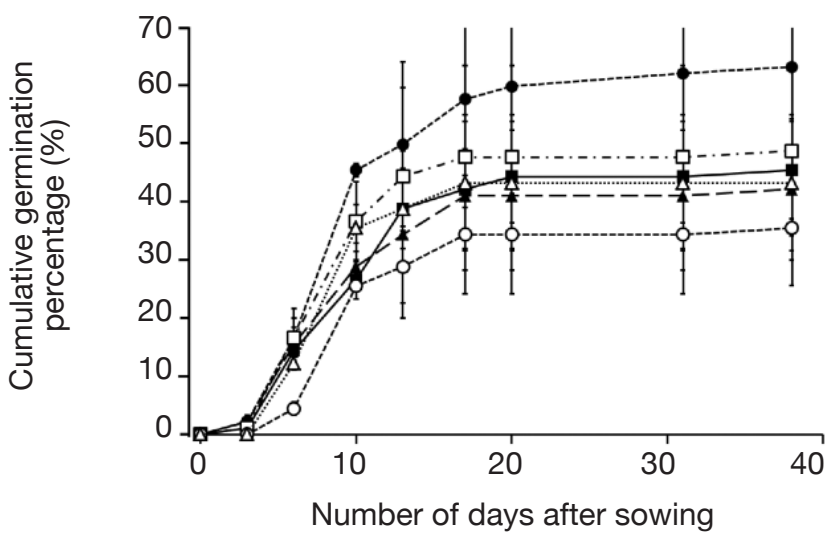

$n=5)$ and for one treatment for C. peschiana (50 $\mu \mathrm{M}$, $n=9)$.

For all analyses, the normality and heteroscedasticity were verified. Root elongation data for C. cobalticola were square-root transformed. All significant differences in analyses were followed by Tukey's range test (HSD) to structure the means. Statistical analyses were performed using the $\mathrm{R}$ statistical software (R Development Core Team, 2010).

\section{RESULTS}

\subsection{Effect of copper on germination}

The final germination percentages were $34.3 \pm 2.4 \%$ for C. cobalticola, $46.0 \pm 2.8 \%$ for $C$. peschiana and $3.0 \pm 0.5 \%$ for C. cornetii. Although no significant differences of the final germination percentage were highlighted between copper concentrations (Figures 2 and $\mathbf{3}$ ), some trends were observed on the cumulative germination curves. The cumulative germination percentage of C.cobalticola at $25 \mu \mathrm{M} \mathrm{Cu}^{2+}$ stayed the lowest (22.0 $\pm 4.8 \%$ at the end of the experiment), while the cumulative germination percentage at $75 \mu \mathrm{M}$

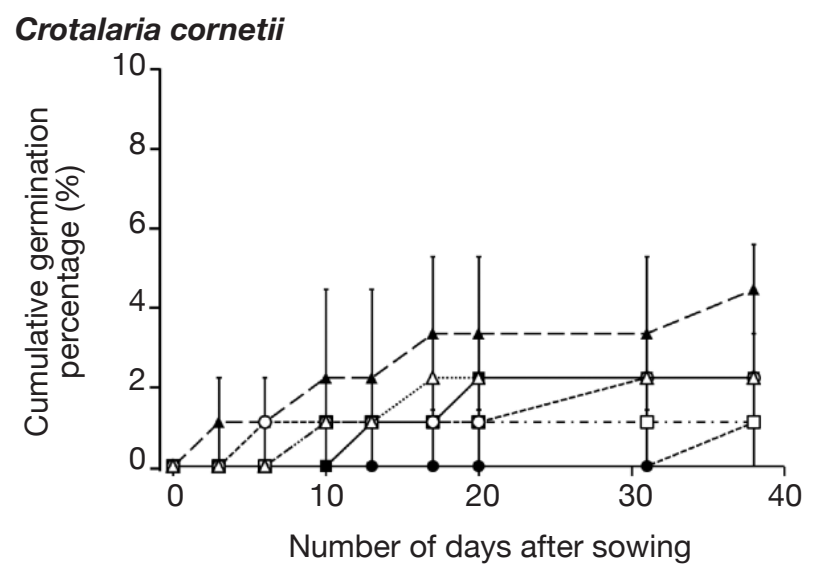

Copper concentrations $(\mu \mathrm{M})$

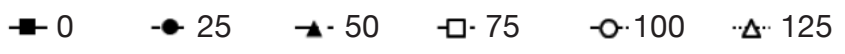

Figure 2. Cumulative germination curves of the percentage of germination $(\%, \mathrm{n}=3)$ of Crotalaria cobalticola, Crotalaria cornetii and Crotalaria peschiana after sowing of seeds in Petri dishes containing six concentrations of copper. Error bars correspond to standard error (SE) - Courbes d'accumulation du pourcentage de germination ( $\%, n=3)$ de Crotalaria cobalticola, Crotalaria cornetii et de Crotalaria peschiana après leur semis en boites de Petri dans six concentrations en cuivre. Les barres d'erreur correspondent à l'erreur standard (SE). 
$\mathrm{Cu}^{2+}$ was the highest from the day $6(42.0 \pm 6.8 \%$ at the end of the experiment). Crotalaria peschiana had the highest cumulative germination percentage at $25 \mu \mathrm{M} \mathrm{Cu}^{2+}(63.3 \pm 6.7 \%$ at the end of the experiment). Crotalaria cornetii, which had overall low final germination percentages, had a highest final germination percentage $(4.4 \pm 1.1 \%)$ at low copper concentrations $\left(0,25\right.$ and $\left.50 \mu \mathrm{M} \mathrm{Cu}^{2+}\right)$. However, no well-defined trend on the cumulative germination curves was observed (Figure 2).

No significant differences of the MGT were highlighted between copper concentrations for C. cobalticola, with a MGT of $7.3 \pm 0.3$ days (Figure 3) and for $C$. peschiana with a MGT equal to $10.8 \pm 0.3$ days (Figure 3). For C. cornetii, the MGT differed according to copper concentrations $(F=5.36$, $p$-value $<0.01)$, seeds tended to germinate more rapidly when copper concentrations increased. The highest MGT was observed for $25 \mu \mathrm{M}$ of copper (35.6 \pm 2.3 days), although it was not significantly different from that at 0 and $50 \mu \mathrm{M} \mathrm{Cu}^{2+}(27.8 \pm 5.3$ days). Its lowest MGT was at $75 \mu \mathrm{M} \mathrm{Cu}^{2+}(3.3 \pm 3.3$ days $)$ that was significantly different than the MGT at $25 \mu \mathrm{M} \mathrm{Cu}^{2+}$ (Figure 3).

\section{Crotalaria cobalticola}

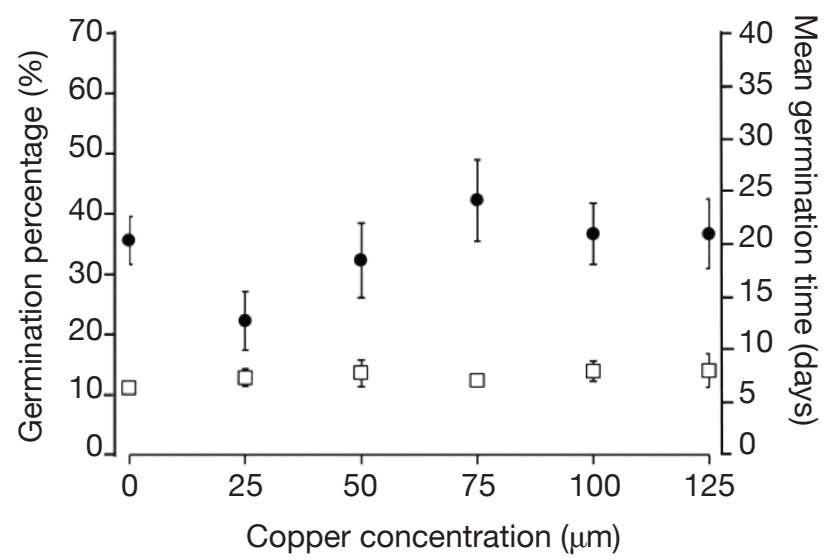

\section{Crotalaria cornetii}

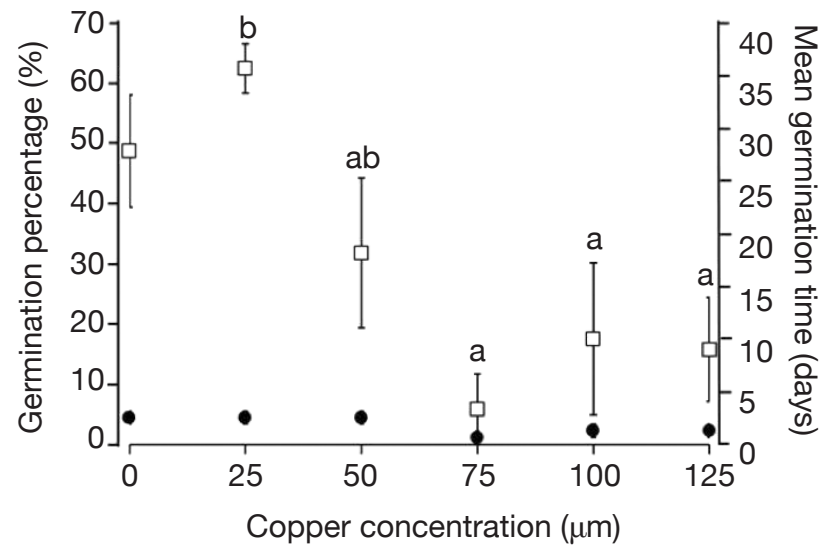

\subsection{Effect of copper on root elongation}

Crotalaria cobalticola had a higher root elongation at $125 \mu \mathrm{M} \mathrm{Cu}^{2+}(150 \pm 41 \mathrm{~mm})$ compared to the other copper concentrations $(F=6.31, p$-value $<0.001$, Figure 4). Crotalaria peschiana presented an equal elongation root uneven the copper concentrations ( $25 \pm$ $1 \mathrm{~mm}$, Figure 4).

\section{DISCUSSION}

\subsection{Germination and early establishment}

The three tropical metallophyte species, $C$. cobalticola, $C$.peschiana and C.cornetii, germinated under all copper concentrations, without a clear effect of copper concentrations on the germination (i.e., germination percentage and mean germination time). This pattern was already pointed out for another copper endemic species Diplolophium marthozianum (Apiaceae) (Boisson et al., 2016). Chipeng et al. (2010) also showed that copper addition did not significantly

\section{Crotalaria peschiana}

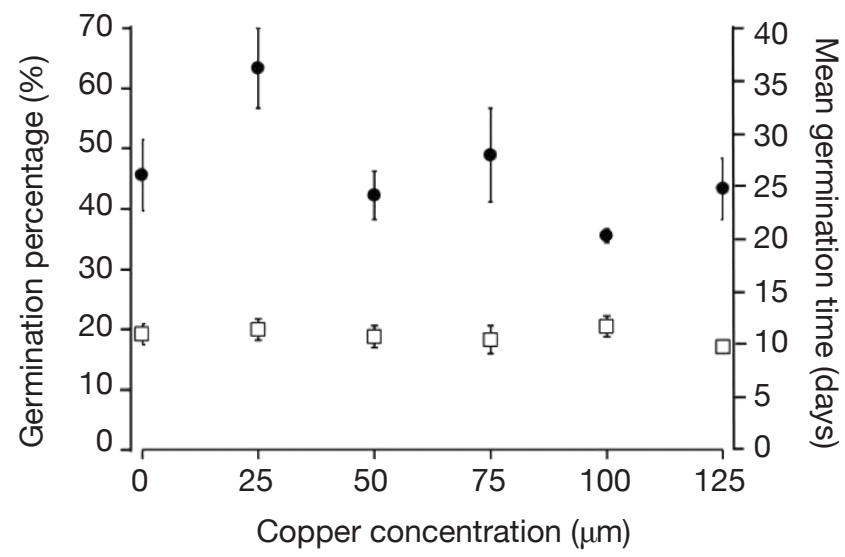

Figure 3. Germination percentages (•) and mean germination time $(\square)$ in days of Crotalaria cobalticola, Crotalaria peschiana and Crotalaria cornetii after 38 days of experiment according to six copper concentration $(\mu \mathrm{M})-$ Pourcentages de germination $(\bullet)$ et temps moyen de germination ( $\square$ ) en jours de Crotalaria cobalticola, Crotalaria cornetii et de Crotalaria peschiana après 38 jours à partir du semis en boites de Petri dans six concentrations en cuivre $(\mu M)$.

The different letters indicate significant $(p$-value $<0.05)$ different means after ANOVA and Tukey's range test (error 5\%). No letter indicates that means are not significantly different - Les lettres différentes indiquent les moyennes significativement différentes (valeur de $\mathrm{p}<0,05$ ) entre elles après l'ANOVA et le test de Tukey (erreur de $5 \%$ ). L'absence de lettres indique que les moyennes ne sont pas significativement différentes. 
Crotalaria cobalticola
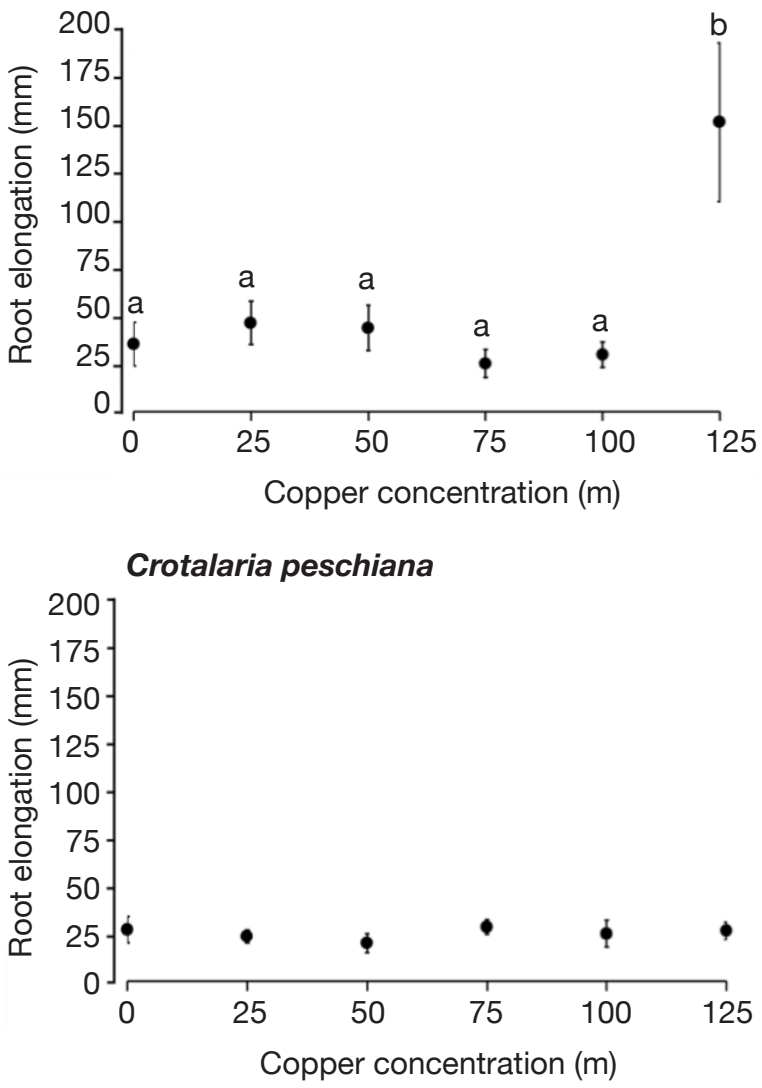

Figure 4. Copperconcentrations effects on the root elongation of Crotalaria cobalticola and Crotalaria peschiana after 28 days of exposition to solutions containing 0, 25, 50, 75, 100 and $125 \mu \mathrm{M} \mathrm{Cu}^{2+}$ - Effet des concentrations en cuivre sur l'élongation racinaire de Crotalaria cobalticola et Crotalaria peschiana après 28 jours d'exposition à des solutions contenant $0,25,50,75,100$ et $125 \mu \mathrm{MCu^{2+ }}$.

Data are presented as the mean root elongation $(\mathrm{mm} \pm \mathrm{SE})$ of 10 seedlings for each concentration but $25 \mu \mathrm{M}(\mathrm{n}=9)$ and $75 \mu \mathrm{M}(\mathrm{n}=5)$ for C. cobalticola and $50 \mu \mathrm{M}(\mathrm{n}=9)$ for C. peschiana - les données sont exprimées en moyennes d'élongations racinaires ( $\mathrm{mm} \pm \mathrm{SE}$ ) de 10 plantules, excepté pour les concentrations $25 \mu M(n=9)$ et $75 \mu M(n=5)$ de C. cobalticola et $50 \mu M(n=9)$ de C. peschiana; dead seedlings were removed from the analysis - les plantules mortes ont été retirées des analyses; error bars correspond to standard error (SE) - les barres d'erreur correspondent à l'erreur standard $(S E)$; letters above dots indicate significant ( $p$-value $<0.05$ ) differences after ANOVA and Tukey's range test - les lettres indiquent les différences significatives (valeur de $\mathrm{p}<0,05$ ) à la suite d'une ANOVA et d'un test de Tukey; means sharing the same letter are not significantly different. No letter indicates that means are not significantly different - les moyennes partageant les mêmes lettres ne sont pas significativement différentes. L'absence de lettres indique que les moyennes ne sont pas significativement différentes.

improve the germination of the high copper tolerant Haumaniastrum katangense (Lamiaceae). On the other hand, Crotalaria cornetii seems more sensitive to higher copper concentration, since this species showed lower mean germination time at the highest copper concentrations. Seed coats can constitute a barrier between the embryo and its direct environment or adsorb metals as reported by previous studies (Mayer et al., 1989; Araújo et al., 2005; Di Salvatore et al., 2008). Seeds of Fabaceae are known for their physical dormancy, where an impermeable seed-coat prevents the entry of water to the embryo (Bewley et al., 1994). The low germination percentages recorded for C. cornetii $(<5 \%)$ may indicate a dormancy of seeds; scarification with sandpaper or soaking in hot water permitted to increase the percentage of germination at $56 \%$ (Le Stradic, personal communication).

The genus Crotalaria permitted to study two endemics that have distinct life histories. Crotalaria cobalticola is an annual species while $C$. peschiana is perennial. Due to the shorter life cycle, annual species have to grow rapidly in order to reproduce (Garnier, 1992). While the percentages of germination were higher for the perennial C.peschiana, the MGT was also longer and could be partially the consequence of the perennial behavior of the species. Crotalaria cobalticola germinates in November and has to produce seeds before the dry season (May). This could explain that the root elongation was higher for C. cobalticola. These two endemic species from the Katangan Copperbelt are classified in the same clade Dispermae contrary to C. cornetii which is in Glaucae (Le Roux, personal communication). This phylogenetic proximity supports supposed higher copper tolerance of C.cobalticola and C.peschiana compared to C. cornetii.

As expected, C.cobalticola, which is a strict endemic of copper hills, was the most copper tolerant species at the early stages of growth (Duvigneaud et al., 1959). Root growth for C. cobalticola was stimulated by highest copper concentration, favoring a rapid development of the individuals, which was not the case for $C$.peschiana at least for the copper concentrations used. Root growth was already reported to be more sensitive than germination to metal toxicity (Jeliazkova et al., 1998; Araújo et al., 2005). Growth stimulation by elevated concentrations of copper has rarely been reported (Faucon et al., 2012). Rapid development of individuals confers an advantage in terms of competition in the highest copper-enriched areas. This high tolerance capacity could also lead to a physiological cost, reducing the fitness and competitive ability of individuals (Cox et al., 1981; Bradshaw, 1984). These assumptions support the hypothesis that this species could not grow in regular soils of the savannahs surrounding the hills where copper content is low ( $\leq 100 \mathrm{mg} \cdot \mathrm{kg}^{-1} \mathrm{Cu}$ ) (Duvigneaud et al., 1959; Saad et al., 2012). Additional studies should focus on a broader range of metal concentrations in 
order to obtain the total copper response curve of the species. Considering that Duvigneaud et al. (1959) has described it as a species highly dependent on cobalt in soils, the identification of its response to cobalt would also be interesting in terms of comparison with copper response.

Crotalaria peschiana was able to grow in all copper concentrations without expressing any quantified stress. Contrary to C.cobalticola, copper seems not to be associated with a physiological need for its growth in the early growth stage; it did not limit its growth either. Crotalaria peschiana is not recorded in non-metaliferous substrate in the Katangan province (Faucon et al., 2010), which implies that this stress-tolerant endemic species might not be limited by edaphic conditions, but is likely excluded from the dominant vegetation by biotic interactions as competition (Gankin et al., 1964) or herbivory. The less productive ability in regular soils leads this species in "refuge areas" (i.e. metalliferous substrates) in which competition is lower (McNeilly et al., 1968). Copper is also known as a broad-spectrum fungicide. Copper-rich soils may have lower pathogen content in comparison to regular soils, conducting to a loss of pathogens defense (Tadros, 1957; Chipeng et al., 2010). Some studies have pointed out the loss of resistance of some copper tolerant species to pathogens (Malaisse et al., 1982; Paton et al., 1996; Chipeng et al., 2010; Faucon et al., 2012). According to the elemental defense hypothesis, metal accumulation in the apoplast can inhibit growth of some bacterial pathogens (Fones et al., 2010). On the copper hills, $C$.peschiana are absent in the steppe where copper concentrations exceed $4,000 \mathrm{mg} \quad \mathrm{Cu} \cdot \mathrm{kg}$ soil $^{-1}$, suggesting that this species tolerates lower copper concentration in soil than $C$. cobalticola (Séleck et al., 2013). Additional studies are required to evaluate the growth response of $C$. peschiana and $C$. cobalticola in higher copper concentrations than $125 \mu \mathrm{M}$ in order to highlight their upper tolerance limits.

\subsection{Conservation of copper endemics and revegetation}

From a conservation point of view, the two endemic and threatened species $C$. cobalticola and $C$. peschiana could be put in germination in non-contaminated mediums, like $C$.cornetii. The ex situ conservation should allow to export and preserve the plant material outside its natural habitat. It is interesting to germinate seeds in vitro before transplanting them in the nursery to keep a maximum of individuals. Then, a non-copper enriched medium would be sufficient to grow these two species during their installation stages, which should facilitate the multiplication of such species. However, more studies should be performed to determine the other factors (i.e. origin of population, biotic interactions or dormancy) which might influence their growth. As the response could be different between populations due to local adaptations, conservation actions should focus on several sites (Faucon et al., 2012; Godefroid et al., 2013; Ilunga wa Ilunga et al., 2013).

In addition,physiological plantresponse to available metals is related to other physico-chemical conditions in soil with all chemical edaphic conditions (Austin, 2007; Soberón et al., 2009), which are not reproduced in our experiments. Similarly, bioavailability of copper and cobalt depends on the total edaphic metal content, $\mathrm{pH}$, clay and hydrous oxide content, organic matter and redox conditions (Reichman, 2002; Saad et al., 2012; Séleck et al., 2013). So, to define a clear relationship between the availability of copper in agar and soils is still difficult (McLean et al., 1992). The determination of the copper and cobalt bioavailability by mathematical models is currently performed in order to study the ecological response to metals of some endemic species and is necessary to improve conservation strategies (Lange et al., 2014).

These results could also contribute to the implementation of other strategies, as revegetation or phytoremediation. The knowledge about ecology of metallophyte endemics is the basis to associate phytotechnologies and ex situ conservation strategies. Secondary habitats created by the mining exploitation are opportunities to preserve part of the threatened metallophyte and endemic species (Whiting et al., 2004; Faucon et al., 2011). These secondary metalliferous habitats present often high physicochemical heterogeneity in metal concentrations and species having a broad response to metals should be preferred. While restoration of mining sites has to be performed after exploitation, ex situ conservation of these metallophyte and endemic species in favorable sites should be a priority, and these secondary habitats created by the mining can be an opportunity to preserve this biological resource.

\section{Acknowledgements}

This study was made possible thanks to the financial intervention of the Fonds de la Recherche dans l'Industrie et dans l'Agriculture (FRIA) and the FNRS (Fonds National de la Recherche Scientifique), Belgium. We also thank to Soizig Le Stradic and Maxime Séleck from the Biodiversity and Landscape Unit for the seed collection on the field and the valuable advices. Sandrine Godefroid from the Botanic Garden Meise who is responsible of the seed conservation and supplied needed seeds for the tests. On field, Tenke Fungurume Mining s.a.r.l. provided the logistic support. 


\section{Bibliography}

Antonovics J., Bradshaw A.D. \& Turner R.G., 1971. Heavy metal tolerance in plants. Adv. Ecol. Res., 7, 1-85.

Araújo A.S.F. \& Monteiro R.T.R., 2005. Plant bioassays to assess toxicity of textile sludge compost. Sci. Agric., 62(3), 286-290.

Austin M., 2007. Species distribution models and ecological theory: a critical assessment and some possible new approaches. Ecol. Modell., 200(1-2), 1-19.

Baker A.J.M. et al., 2010. Metallophytes: the unique biological resource, its ecology and conservational status in Europe, central Africa and Latin America. In: Batty L. \& Hallberg K., eds. Ecology of industrial pollution. Cambridge, UK: Cambridge University Press, 7-40.

Bewley J.D. \& Black M., 1994. Seeds: physiology of development and germination. New York, USA: Plenum Press.

Boisson S. et al., 2016. No copper required for germination of an endangered endemic species from the Katangan Copperbelt (Katanga, DR Congo): Diplolophium marthozianum. Trop. Ecol., in press.

Bradshaw A.D., 1984. Adaptation of plants to soils containing toxic metals - a test for conceit. In: Evered D. \& Collins G.M., eds. Origins and development of adaptation. London: Pitman, 4-19.

Brady K.U., Kruckeberg A.R. \& Bradshaw Jr. H.D., 2005. Evolutionary ecology of plant adaptation to serpentine soils. Annu. Rev. Ecol. Evol. Syst., 36(1), 243266.

Brooks A., Collins J.C. \& Thurman D.A., 1981. The mechanism of zinc tolerance in grasses. J. Plant Nutr. 3(1-4), 695-705.

Brooks R.R. \& Malaisse F., 1985. The heavy metal tolerant flora of Southcentral Africa: a multidisciplinary approach. Rotterdam, The Netherlands: A.A. Balkema.

Brooks R.R., Baker A.J.M. \& Malaisse F., 1992. Copper flowers. Res. Explor., 8(3), 338-351.

Cailteux J.L.H. et al., 2005. Genesis of sediment-hosted stratiform copper-cobalt deposits, central African copperbelt. J. Afr. Earth Sci., 42(1-5), 134-158.

Chipeng F.K. et al., 2010. Copper tolerance in the cuprophyte Haumaniastrum katangense (S. Moore) P.A. Duvign. \& Plancke. Plant Soil, 328(1-2), 235-244.

Cox R.M. \& Hutchinson T.C., 1981. Multiple and cotolerance to metals in the grass Deschampsia cespitosa: adaptation, preadaptation and cost. J. Plant Nutr., 3, 731-741.

Di Salvatore M., Carafa A. \& Carratù G., 2008. Assessment of heavy metals phytotoxicity using seed germination and root elongation tests: a comparison of two growth substrates. Chemosphere, 73(9), 1461-1464.

Duvigneaud P. \& Timperman J., 1959. Études sur la végétation du Katanga et de ses sols métallifères. Communication $\mathrm{n}^{\circ} 3$. Études sur le genre Crotalaria. Bull. Soc. R. Bot. Belg., 91(2), 135-176.
Duvigneaud P. \& Denaeyer-De Smet S., 1963. Études sur la végétation du Katanga et de ses sols métallifères. Communication $\mathrm{n}^{\circ} 7$. Cuivre et végétation au Katanga. Bull. Soc. R. Bot. Belg., 96(2), 93-231.

Ellis R.H. \& Roberts E.H., 1981. The quantification of ageing and survival in orthodox seeds. Seed Sci.Technol., 9, 373-409.

Ernst W.H.O., 1974. Schwermetallvegetation der Erde. Stuttgart, Deutschland: G. Fisher ed.

Faucon M.-P.etal.,2010. Copper endemism in the Congolese flora: a database of copper affinity and conservational value of cuprophytes. Plant Ecol. Evol., 143(1), 5-18.

Faucon M.-P. et al., 2011. May rare metallophytes benefit from disturbed soils following mining activity? The case of the Crepidorhopalon tenuis in Katanga (D. R. Congo). Restor. Ecol., 19(3), 333-343.

Faucon M.-P. et al., 2012. Copper tolerance and accumulation in two cuprophytes of South Central Africa: Crepidorhopalon perennis and C.tenuis (Linderniaceae). Environ. Exp. Bot., 84, 11-16.

Fones H. et al., 2010. Metal hyperaccumulation armors plants against disease. PLoS Pathog., 6(9), 1-13.

François A., 1988. Synthèse géologique sur l'Arc cuprifère du Shaba (Rép. du Zaïre). Soc. Belg. Géol., HS, 1565.

Gankin R. \& Major J., 1964. Arctostaphylos myrtifolia, its biology and relationship to the problem of endemism. Ecology, 45(4), 792-808.

Garnier E., 1992. Growth analysis of congeneric annual and perennial grass species. J. Ecol., 80(4), 665-675.

Godefroid S. et al., 2013. Germination capacity and seed storage behaviour of threatened metallophytes from the Katanga copper belt (DR Congo): implications for ex situ conservation. Plant Ecol. Evol., 146(2), 183-192.

Harrison S.P. \& Rajakaruna N., 2011. Serpentine: the evolution and ecology of a model system. Berkeley, CA, USA: University of California Press.

Ilunga wa Ilunga E. et al., 2013. Small-scale diversity of plant communities and distribution of species niches on a copper rock outcrop in Upper Katanga, DR Congo. Plant Ecol. Evol., 146(2), 173-182.

Jeliazkova E.A., Jeliazkov V.D., Craker L.E. \& Xing B., 1998. Heavy metals and seed germination in medicinal and aromatic plants. HortScience, 33(2), 206.

Kruckeberg A.R., 1985. California serpentines: flora, vegetation, geology, soils, and management problems. Berkeley, CA, USA: University of California Press.

Lange B. et al., 2014. Prediction of the edaphic factors influence upon the copper and cobalt accumulation in two metallophytes using copper and cobalt speciation in soils. Plant Soil, 379(1-2), 275-287.

Le Roux M.M., Van Wyk B.E., Boatwright J.S. \& Tilney P.M., 2011. The systematic significance of morphological and anatomical variation in fruits of Crotalaria and related genera of tribe Crotalarieae (Fabaceae). Bot. J. Linn. Soc., 165(1), 84-106. 
Leteinturier B.,2002.Évaluation dupotentielphytocénotique des gisements cuprifères d'Afrique centro-australe en vue de la phytoremédiation de sites pollués par l'activité. Gembloux, Belgique : Faculté universitaire des Sciences agronomiques de Gembloux.

Leteinturier B. \& Malaisse F., 2002. On the tracks of botanical collectors on copper outcrops of South Central Africa (in French). Syst. Geogr. Plants, 71, 133-163.

Lin Y., 2011. Effects of copper ion on seeds germination of Cichorium intybus L. determined by agar plate method. J. Hebei Agric. Sci., 10.

Malaisse F., 1983. Phytogeography of the copper and cobalt flora of Upper Shaba (Zaïre), with emphasis on its endemism, origin and evolution mechanisms. Bothalia, 14, 497-504.

Malaisse F., Brooks R.R. \& North P., 1982. Colonisation of modified metalliferous environments in Zaire by the copper flower Haumaniastrum katangense. Plant Soil, 64, 289-293.

Mayer A.M. \& Poljakoff-Mayber A., 1989. The germination of seeds. New York, USA: Pergamon Press.

McLean J. \& Bledsoe B.E., 1992. EPA Ground water issue. Behavior of metals in soils. Washington: NSCEP.

McNeilly T. \& Bradshaw A.D., 1968. Evolutionary processes in populations of copper tolerant Agrostis tenuis Sibth. Evolution, 22(1), 108-118.

Meyer S., 1986. The ecology of gypsophile endemism in the eastern Mojave Desert. Ecology, 67(5), 1303-1313.

Palacio S. et al., 2007. Plants living on gypsum: beyond the specialist model. Ann. Bot., 99(2), 333-343.

Paton A. \& Brooks R.R., 1996. A re-evaluation of Haumaniastrum species as geobotanical indicators of copper and cobalt. J. Geochem. Explor., 56, 37-45.
$\mathrm{R}$ Development Core Team, 2010. A language and environment for statistical computing. Vienna: R Foundation for Statistical Computing ed.

Rajakaruna N., 2004. The edaphic factor in the origin of species. Int. Geol. Rev., 46, 471-478.

Reichman S., 2002. The responses of plants to metal toxicity: a review focusing on copper, manganese \& zinc. Prahan, Victoria, Australia: Australian Minerals \& Energy Environment Foundation.

Saad L. et al., 2012. Investigating the vegetation-soil relationships on the copper-cobalt rock outcrops of Katanga (D. R. Congo), an essential step in a biodiversity conservation plan. Restor. Ecol., 20(3), 405-415.

Séleck M. et al., 2013. Chemical soil factors influencing plant assemblages along copper-cobalt gradients: implications for conservation and restoration. Plant Soil, 373(1/2), 455-469.

Soberón J. \& Nakamura M., 2009. Niches and distributional areas: concepts, methods, and assumptions. Proc. Natl. Acad.Sci. U.S.A., 106(2), 19644-19650.

Tadros T.T.M., 1957. Evidence of the presence of an edaphobiotic factor in the problem of serpentine tolerance. Ecology, 38(1), 14-23.

Veldman J.W. et al., 2015. Tyranny of trees in grassy biomes. Science, 347(6221), 484-485.

Whiting S.N. et al., 2004. Research priorities for conservation of metallophyte biodiversity and their potential for restoration and site remediation. Restor. Ecol., 12(1), 106-116.

(53 ref.) 